\title{
1069. Pharmacological preconditioning with vitamin c attenuates intestinal injury via the induction of heme oxygenase-1 after hemorrhagic shock in rats
}

\author{
B Zhao*, J Fei, Y Chen, X-Q Song, L Ma, L Wang, E-Z Chen, E-Q Mao \\ From ESICM LIVES 2014 \\ Barcelona, Spain. 27 September - 1 October 2014
}

\section{Introduction}

Pre-induction of heme oxygenase $(\mathrm{HO})-1$, which is regarded as an effective method of "organ preconditioning", exerts beneficial effects during hemorrhagic shock (HS). However, the available HO-1 inducers exhibit disadvantages such as toxicity or complex technical requirements. Therefore, a safe and convenient HO-1 inducer would be promising and could be exploited in the treatment of foreseeable hemorrhaging, such as prior to major surgery. Recently, vitamin C (VitC) has been shown to attenuate organ injuries and inhibit inflammatory responses in hemorrhagic shock [3], but the specific mechanism remains unclear. Studies on the relationship between $\mathrm{HO}-1$ and VitC are limited, and the results are controversial $[4,5]$.

\section{Objectives}

We investigated the effect of vitamin $\mathrm{C}$ (VitC) on intestinal HO-1 expression and the involved mechanism. We further investigated if VitC pretreatment prevented HS related intestinal tissue injuries via $\mathrm{HO}-1$ induction.

\section{Methods}

The IEC- 6 were treated with grade concentration of VitC as well as SB203580, PD98059 and SP600125, the inhibitors of p38 mitogen-activated protein kinase (MAPK), extracellular signal-regulated kinase (ERK) $1 / 2$ and c-Jun N-terminal kinase (JNK). SD rats were pretreated with VitC (intraperitoneally, 100mg/Kg), HS was induced by drawing blood from the rat femoral artery (mean arterial pressure $=30 \mathrm{~mm} \mathrm{Hg}$ ) for $1 \mathrm{hr}$ and resuscitating with the shed blood and Ringer's solution. Some rats further received zinc protoporphyrin (Znpp, intraperitoneally, $3 \mathrm{mg} / \mathrm{kg}$ ), a $\mathrm{HO}-1$ inhibitor.

\section{Results}

The in vitro study showed HO-1 was induced in IEC6 cell in a time- and concentration- dependent manner by VitC, and the inhibitor of ERK1/2 PD98059 inhibited the VitC induced HO-1 expression. The in vivo study showed the HO-1 protein (mainly observed in intestinal epithelial cells) and activity in intestine were highly induced in normal rat, and these $\mathrm{HO}-1$ levels were further enhanced in HS rat model. The histological damage, apoptosis (number of TUNEL positive cell, $\mathrm{Bcl}-2 / \mathrm{Bax}$ ratio), neutophil infiltration (number of MPO positive cells, MPO activity and MPO protein level), and inflammatory cytokines level of tumor necrosis factor-a and interleukin- 6 were all relieved by VitC pretreatment, and the protective effect of VitC was attenuated by Znpp.

\section{Conclusions}

These data suggests VitC might be applied as a safe inducer of intestinal HO-1 and VitC pretreatment attenuated HS related intestinal injuries via induction of HO-1 by activating ERK1/2 pathway.

\section{Grant acknowledgment}

This work is supported by National Natural Science Foundation of China projects 81171789 


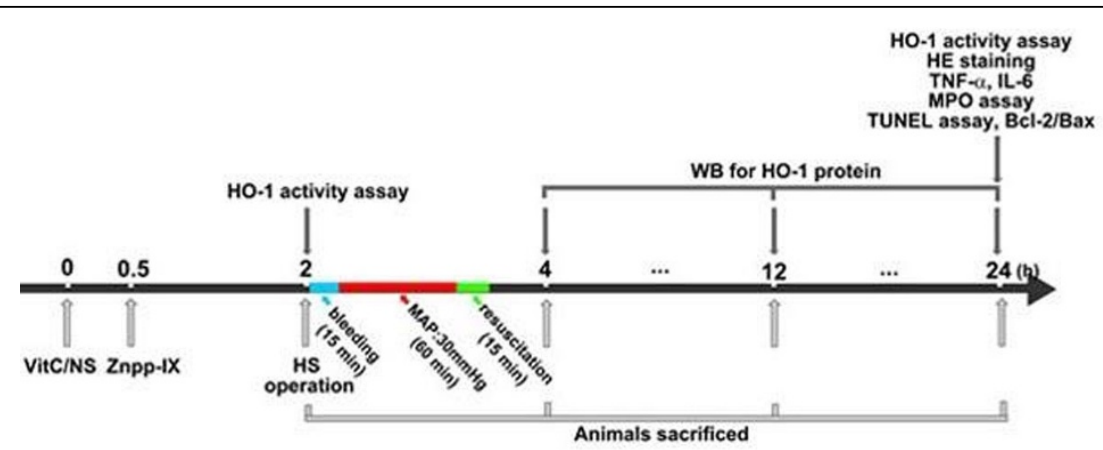

Figure 1 The schematic diagram of the main in vivo protocol

Published: 26 September 2014

\section{References}

1. Kubulus D, et al: Shock 2008, 29(5):583-590.

2. Raddatz A, et al: American journal of respiratory and critical care medicine 2006, 174(2):198-207.

3. Van PY, et al: The Journal of trauma 2011, 71(1):20-24, discussion 24-25.

4. Kim JY, Lee SM: Life sciences 2004, 75(16):2015-2026.

5. Elbekai RH, et al: Cancer letters 2007, 246(1-2):54-62.

doi:10.1186/2197-425X-2-S1-P85

Cite this article as: Zhao et al:: 1069. Pharmacological preconditioning with vitamin $c$ attenuates intestinal injury via the induction of heme oxygenase-1 after hemorrhagic shock in rats. Intensive Care Medicine Experimental 2014 2(Suppl 1):P85.

\section{Submit your manuscript to a SpringerOpen ${ }^{\circ}$ journal and benefit from:}

- Convenient online submission

- Rigorous peer review

- Immediate publication on acceptance

- Open access: articles freely available online

- High visibility within the field

- Retaining the copyright to your article

Submit your next manuscript at $>$ springeropen.com 